The Myth of Political Correctness 



\section{The Myth}

of

T H E

Political

C ON SER VATIVE

Correctness

A T T A C K

$\mathrm{ON}$

John K. Wilson

H I G H E R

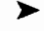

E D U C A T I O N

D U KE UN IVERS I T Y PRESS Durham and London 1995 
Third printing, 1998

(C) 1995 Duke University Press

All rights reserved

Printed in the United States of America on acid-free paper $\infty$ Typeset in Minion by Tseng Information Systems, Inc.

Library of Congress Cataloging-in-Publication Data appear on the last printed page of this book. 
To all my teachers 
